\title{
RE-FRAMING THE SPANISH CIVIL WAR AS 'CULTURAL TRAUMA': WHEN RESPONSIBILITIES GET BLURRED AFTER VIOLENCE
}

Keywords: Spanish Civil War; cultural trauma; violence; responsibility; victimhood; perpetrators; the war of madness.

Abstract: The aim of this article is to address to what extent some institutional form of remembering the Spanish Civil War (1936-1939) as a collective trauma could be considered an instance of Jeffrey Alexander and Neil Smelzer's notion of 'cultural trauma'. Or to put it in other words, in which sense the notion of cultural trauma may cast a new light on one of the different ways in which the Spanish Civil War was remembered and retold during the transition to democracy (1977-83). Spanish society remembered the war as a collective trauma, so painful that it encouraged society to promote a 'pact of oblivion' toward victims of Francoist repression. According to this traumatic memory, the Spanish Civil War was a 'fratricidal struggle', whose outbreak was a consequence of the tensions that underlie Spanish history. It led to the blurring of distinctions between victims and culprits because both sides were considered equally responsible. Therefore, everyone could claim the ownership of suffering. However, this representation did not fit in with the historical records; it was a consequence of the social influence of some 'memory makers' that developed new narratives and re-defined the ownership of suffering. Because of this divergence between the historical record of the war and society's traumatic memory of it during the transition to democracy, I would like to analyse the possibility of studying the nature of the latter by means of the concept of cultural trauma. After all, Alexander's critique of psychoanalytical insight into collective trauma could be useful when analysing traumatic historical experiences where it is not clear whether the traumatic nature of those memories come from the events themselves or from the cultural frames that attributed significance to those events.

Some specialists in the Spanish Civil War from different fields have used the notion of collective trauma but in such different and heterogeneous ways that its implications are still problematic. By resorting to collective trauma they were not just using it as a metaphor or a narrative device. Rather, it worked as an explanatory resource for understanding the evolution of legacies of violence during the dictatorship (1939-1977) and, especially, the transition to democracy.

Both events during the war and post-war events may help to understand why the historical experience of the Spanish Civil War has been remembered and framed as a collective trauma. During the years of the war, around 470,000 people were killed on the battlefield. These numbers were increased by the repression carried out on the red guards rearguards, which was extremely harsh. Approximately, 50,000 people

\footnotetext{
${ }^{*}$ University of Murcia; Spain.
} 
were shot by the radical groups that supported the Spanish Republic; just a third of the number of victims that were killed by the rebel authorities, who controlled more territory. The contrasting levels of violence on both sides increased during the postwar period. After winning the war, the Francoist authorities established a dictatorship that lasted almost forty years and was characterised by a politics of punishment and ideological and political repression against the vanquished that caused 50,000 more victims among those who supported the Spanish Republic (Graham) (Preston). Moreover, thousands of peoples were forced to go into exile (Alted) or were imprisoned in overpopulated prisons (Rodrigo). Both the destruction of the Civil War and the harshness of the repression during the post-war period may explain why this event has been frame das a collective trauma. Nonetheless, the unfolding of catastrophic events that shattered the social foundation of Spanish society was not the only reason that encouraged historians and sociologists to resort to the notion of collective trauma for depicting the Spanish Civil War's legacy. Also very influential was the way Spanish society and political elites dealt with the after-effects of those events following the end of the Francoist dictatorship. As pointed out by different historians, during the transition to democracy neither truth nor justice was granted towards the victims of the war and Francoist repression. On the contrary, most parts of society promoted what has been called a 'pact of forgetting' towards the Spanish Civil War. Following the dictatorship, no responsibility was assigned; quite the opposite. A blank amnesty which covered all the crimes committed by the Francoist authorities was enacted in 1977 by the Spanish parliament. Despite the huge amount of historical research conducted during those years, within the public sphere the unsettling memories of the war were avoided and silenced. For this reason, both the horrors of the war and the silence towards those events has been explained by taking the disrupting temporality of trauma as a reference. If the traumatized, as Caruth asserted, "carry an impossible history within them [...] that they cannot entirely posses" (Caruth, Unclaimed 8), the pact of forgetting will be understood in the collective field as the suppression of the overwhelming experience of the war. Both the destruction of the Civil War, the harshness of the post-war repression and the silence during the transition to democracy may explain why this event has been framed as a collective trauma. By means of this notion, some historians tried not only to address the hyperbolic and excessive dimension of the violence, but also to explain why Spanish society choose to forget the historical debts accrued for the crimes during the transition to democracy. In her famous study Democracy whiteout justice Omar Encarnación asserts:

The most popular explanations for the rise of forgetting in Spain all relate to how the traumas of the past affected the political mindset of the Spanish political elite and society at large around the time of the democratic transition. The best known among these "psycho-political" explanations is the theory of memoria traumatic, which stresses that during the transition the Spaniards willed themselves into political amnesia as a direct consequence of the collective traumas inflicted by the Civil War and the postwar period (Encarnación 18).

Nonetheless, by delving further into the grounds of the traumatic conditions of the Spanish Civil War, this papers aims to go beyond the assumption that underlies 
Trauma, Narrative and Responsibility

Caruth's approach, in a way that will be presented along the following lines. In considering the 'collective trauma' of the Spanish Civil War I will not just focus on the unsettling events of the war and the post-war period. Rather, I will specifically refer to the public discourse regarding the conflict that was originated in the last years of Francoism and spread thorough Spanish society during the transition to democracy. This is a collective trauma which was not derived directly from the experiences suffered by particular individuals. On the contrary, it was developed through the retrospective reconstruction of the events. It was the product of the depiction of the Civil War which defines it by means of such tropes as national tragedy, historical tragedy, "the war of the madness" madmen's war, war between brothers, etc. As far as this public representation is concerned, during those years, all of Spanish society was caught up in an irrational and pathological spiral of violence that both sides, Francoist and Republican, winners and vanquished, fed into. According to this depiction, the Spanish Civil War was thus just a chaotic and unbearable burst of violence for which both sides should be held equally responsible. By asserting the relevance of this depiction for understanding the collective memory of the Spanish Civil War, I am not denying that there were traumatic memories linked to experiences suffered by individuals. But those public discourses that re-shaped the Spanish Civil War as a 'national tragedy' or 'the war of the madness' are deeply interwoven with how the war was remembered by the social actors that were engaged in the conflict and by their offspring.

At this point, it is necessary to delve into the notion that gives the name to my presentation: cultural trauma. The ground-breaking approach of Jeffrey Alexander and Neil Smelzer, among other authors, to collective trauma has reshaped how this notion is understood and applied to history and highly suggests the possibility of applying it to the study of the aforementioned public discourse that re-framed the Spanish Civil War as a 'the war of the madness. Their reflections regarding cultural trauma depart from underpinning the assumptions that underlie psychoanalytical and psychosocial approaches to collective trauma. The main example of this psychoanalytical approach to collective trauma is located in Cathy Caruth and Kai Erikson's works. In her classic study Unclaimed Experiences, Caruth asserted that trauma is located "in the way that its very unassimilated nature - the way it was precisely not known in the first instance - returns to haunt the survivor later on"(Caruth, Unclaimed 4), which means that the story of a trauma is thus the 'story of a wound that cries out'. What Alexander tries to highlight is that by defining trauma in such a way, Caruth is assuming that it is the abruptness of the traumatic experience that keeps it from being available to consciousness and causes it to be buried in the unconscious. The emergence of trauma thus depends mainly on the unsettling nature of the experience, in the gap that arises between event and consciousness. No matter how compelling this definition may be for understanding clinical trauma, according to Alexander and Smelzer, it is not helpful for bringing light to the complex processes which underlie collective trauma. In this regard, their reflections regarding cultural trauma depart from disclosing the naturalistic fallacy that, from their perspective, underlies the psychoanalytical approach to collective trauma. This fallacy could be summarized as follows: it is the harsh nature of some events which makes them unbearable and which makes them become distorted in the subject's memory, provoking traumatic symptoms in 
consciousness. More specifically, Alexander and Smelzer's critique focuses on the projection of this model onto the collective level, which is exemplified by Kai Erikson's work regarding the effects of a devastating flood on the community of Buffalo. Erikson depicted this historical experience as a collective trauma insofar as the overwhelming experience of the floods shattered the social structures of trust and communication within the group. The painful wounds inflicted on the social group became a permanent state of the community. In this regard, Erikson's definition of collective trauma assumes the analogy with individual trauma. This analogy relies on the aforementioned assumption which identifies trauma with just the harshness and abruptness of events. As he summarized in Everything in Its Path:

By individual trauma I mean a blow to the psyche that breaks through one's defenses so suddenly and with such brutal force that one cannot react to it effectively. By collective trauma, on the other hand, I mean a blow to the basic tissues of social life that damages the bonds attaching people together and impairs the prevailing sense of communality. The collective trauma works its way slowly and even insidiously into the awareness of those who suffer from it, so it does not have the quality of suddenness normally associated with "trauma". But it is a form of shock all the same, a gradual realization that the community no longer exist as an effective source of support and that an important part of the self has disappeared (Erikson, Everything 153-4).

In total opposition to this common interpretation, Neil Smelzer argues that a collective trauma 'refers to an invasive and overwhelming event that is believed to undermine or overwhelm one or several essential ingredients of a culture or the culture as a whole'. It is precisely that this is believed which defines the main contribution of cultural trauma theory to the issue at hand. In contrast to theories of collective trauma inspired by psychoanalysis, Alexander and Smelzer argue that the emergence of collective traumas does not only come from the harshness of the events themselves, but from how those events were retrospectively depicted. Collective trauma is the product of a cultural memory, influenced by politics of the past, which, by means of symbolic resources, created a cultural framework that redefines the past as traumatic. Therefore, the cultural trauma approach ultimately changes the field and the concerns that are at stake when dealing with legacies of traumatic violence. Is not only necessary to deal with how harsh the events where or how their intensity broke the channels of inter-subjective communication, but also with who is depicting those events as traumatic and which social and political implications this cultural memory will have. Alexander and Smelzer's re-framing of collective trauma echoes the perpetual international discussions regarding trauma and victimization. After all, the main consequence of depicting an event as traumatic is not just to verify the nature of the events. It also leads to defining the ones who suffered the overwhelming experience as victims, who have a right to reparation. Moreover, when traumatic events depend on human action, the historical agents that provoked it will be publicly recognized as perpetrators who must redeem themselves. Therefore, depicting the events as collective trauma cannot be detached from issues regarding responsibility. Here lies the main difference between the cultural trauma approach and the approach proposed by Erikson. After all, the historical example that sparked Erikson's 
reflections was a natural catastrophe; no human agency was behind it. For this reason, questions regarding who bears responsibility for it could not arise. As he asserted in "Notes on Trauma and Community": "Natural disasters are experienced as acts of God or whims of nature. They occur to us. They visit us, as if from afar... It is almost impossible to imagine a commission of inquiry, called to discover the causes of some dreadful accident, concluding “well, it just happened”” (Erikson, 'Notes on’ 191).

In contrast, Alexander's critique makes the scope of collective trauma wider, insofar as he includes events which depend heavily on human agency, which lead to the emergence of social mechanisms for looking for the ones to blame. Alexander maintained that by characterising a social depiction as 'cultural trauma' public institutions always define 'antagonistic figures', who are identified as perpetrators who bear responsibility for the crimes committed. In order to end this presentation concerning the contributions of the cultural trauma category to trauma studies, I should be delve within the different ways in which the aforementioned authors framed the relations between trauma and narrative. According to Caruth, trauma and narrative are allergic to each other. Traumatic events 'cannot become part of a narrative memory' (Caruth, Explorations 153). In contrast, Alexander and Smelzer assume that the construction of trauma depends on a narrative which retrospectively defines events as traumatic. As Alexander defended:

Representation of trauma depends on constructing a compelling framework of cultural classification. In one sense, this is simply telling a new story. Yet this storytelling is, at the same time, a complex and multivalent symbolic process that is contingent, highly contested, and sometimes highly polarizing. (Alexander, “Towards a Theory" 12)

To sum up, there are two ideas that can be taken from Alexander and Smelzer's approach to collective trauma: (1) for a historical experience to become a collective trauma depends on "the postfacto interplay of political power, social relationship and agency", and (2) those institutional claims regarding collective traumas always lead to the definition and delimitation of victims and culprits. The semantic weights that come from suffering those collective experiences explain why cultural traumas so often devolve to the symbolic mechanisms of scapegoating and collective acquittal. Cultural trauma is thus bound to the redistribution of accountability. The purpose of the following section will be to delve further into the possibility of applying these two assumptions to the collective memory of the Spanish Civil War which I already defined. This approach will provide an opportunity to further investigate the assumptions underlying Michael Richards's ground-breaking study. His After the Civil War addresses how the Spanish Civil War was remembered and retold during the following decades by means of cultural trauma (Richards).

This particular interpretation of collective trauma would allow us to explain why the origin and transmission of the aforementioned public memory of the Spanish Civil War is always a contested issue through which political and cultural factors are always interwoven.' Historical tragedy', 'madmen's war'... these monikers endow the Spanish Civil War with an hyperbolic semantic weight that allow us to define it as cultural trauma. As a consequence, meanings and responsibilities that had been charged to traumatic events or to traumatized actors are always being re-shaped as the 
years go by. Furthermore, the post hoc and backwardness dimensions of cultural trauma point to the historical context in which those depictions are embedded. After all, the memory of the Civil War as a 'collective tragedy' did not emerge automatically; neither was it transmitted directly by witnesses. Rather it depended on institutional depictions about the war that started to emerge, as Pablo Sánchez and Jesús Izquierdo have argued, in the last years of Francoism. The social and political agencies which underlie cultural trauma allow us to explain why this depiction of the war fits in so well with the purposes of some politics of the past. Therefore, it will be necessary to deal with the historical origins of this depiction of the war.

My reflection regarding the historical origin of this depiction of the past that will be considered as an instance of cultural trauma will depart from focusing on the politics of memory carried out by Francoist authorities after the conflict. Starting in April 1939, public institutions started to build a depiction of that past that re-shaped it as a 'war of national liberation'. According to that depiction, those who supported the Francoist rebellion were saviours and national heroes, whereas the vanquished were anti-Spanish scum who followed the commands of Russian bolshevism in order to support Spanish traditional roots. As a consequence, those who died fighting for the Francoist revolt were framed as the only victims that deserve that name. However, as the decades passed, the public memory of the Civil War as a movement for national liberation started to fade. The necessity of cleaning up the image of Spain internationally within a Cold War context and the passage of generations somewhat caused this discourse of victory to be substituted by a discourse for reconciliation. The Spanish historians Pablo Sánchez León and Jesús Izquierdo mentioned a biographical experience concerning these changes of memory that is really meaningful. In the hall of their school there was a marble plaque with a message inscribed that asserted: "This building, which was destroyed by Marxist hordes during our War for National Liberation, was rebuilt by Generalísimo Francisco Franco” During the seventies, this message was substituted by another which read: "This building, which was destroyed as a consequence of horrors of war, was rebuilt by Generalísimo Francisco Franco" (Sánchez and Inzquierdo 223).

From 'Marxist hordes' to 'horrors of the war', from the justification of repression to a struggle for reconciliation -this was the shift concerning the politics of memory. According to this depiction, all of Spanish society was caught up in an irrational and pathological spiral of violence that both sides, Francoist and Republican, winners and vanquished, fed into. This depiction relied on psychological terminology that framed historical actors as pathologized, which is the main reason for understanding it as an instance of cultural trauma. According to this depiction, the Spanish Civil War was called a' historical tragedy', 'madmen's war' or 'national tragedy'. Those are the main tropes that underlie the institution of this national trauma.

Despite the fact that this public memory of the Civil War as 'collective madness' originated in the last years of Francoism, it needed to be reproduced and reactivated during the decades that follow in order to keep its influence among Spanish society. As Neil Smelzer argues, "once a historical memory is established as a national trauma for which the society has to be held in some way responsible, its status as trauma has to be continuously and actively sustained and reproduced in order to continue in that status" (Smelzer 38). Thus, some 'carrier groups', some memory 
makers, contributed to promoting the social influence of this depiction of the Spanish Civil War, which totally fits in with the one previously defined. In this regard, Alexander and Smelzer's theories regarding how the institutional arena and mass media are essential to the institution and social success of those depictions totally fit in with the role played by some mnemonic agents - newspapers, textbooks, films, etc. - in transmitting this depiction of the war. Despite the fact that it originated in the last years of Francoism, this depiction needed to be reproduced and reactivated during the decades that followed, in order to maintain its influence in Spanish society.

Among those 'carrier groups' may be counted the newspapers, textbooks and some popular films produced during those years. For instance, the newspaper El País published some opinion pieces which resort to a depiction of the Civil War as a chaotic tragedy whose memory should be forsaken by Spanish society in order to build the foundation of democracy. In Paloma Aguilar's words, "In El País [...] the war was depicted as a barbaric and unnecessary tragedy, which had to be recalled in order to prevent its repetition” (Aguilar 215). Secondly, in the early seventies school textbooks, when dealing with this part of Spanish history, began to promote a depiction of the war that converges with the one that reframed it as a 'collective madness'. The Spanish Civil War was placed within a context of the 'difficult modernization of society' which finally resulted in the fading of any personal responsibility for the crimes committed. Finally, some films should be recognised. Special mention should be given to Manolo Majtics film 'The Madmen's War', ' $\mathrm{La}$ guerra de los locos'. The film takes place in the context of the Spanish Civil War, specifically in an asylum which was caught up in the midst of the struggles. As a consequence of the events of the war, the authorities loses control of the mental asylum, which lets inmates free. Several of the lunatics form a group that manage to get hold of some weapons and kill anybody prepared to take them, no matter to which side they belong. This behaviour was a metaphor for the Spanish Civil War, which was depicted as a collective madness to which all of Spanish society is equally victim and responsible party. In her book Memory and Amnesia, Paloma Aguilar describes how Majtic's film conveys a depiction of the past that can be considered an instance of cultural trauma. She synthesized it in the following terms:

In fact, this is the message that the Spanish film (La guerra de los locos) attempted to convey. [...] This attitude, however, was not especially anomalous within the context of the civil war, as everyone involved in the conflict seems to have gone insane, although, unlike the protagonist of the film, their insanity may have only been temporary” (Aguilar 210).

To sum up, the first idea provided by cultural trauma totally fits in with the historical case I am dealing with. Nevertheless, the second idea highlighted before cannot be thoughtfully applied to the Spanish case so easily. A will be drawn, a depiction of the Spanish Civil War in which cultural trauma does not lead to the identification of 'antagonistic figures'; quite the opposite. It is precisely the absence of such figures in Spanish society during the seventies and eighties which paved the way for the amnesty granted for the crimes of the dictatorship.

The Spanish Civil War's depiction as a 'madmen's war' led to a new distribution of accountability and victimhood which tends to blur both the definition 
of victims and perpetrators. After all, the aforementioned distribution of responsibilities is one of the main features of collective memories which constitute cultural trauma. As Jeffrey Alexander argues: "In creating a compelling trauma, it is critical to establish the identity of the perpetrator, the "antagonist". Who actually injured the victim? Who caused the trauma?”(Alexander, 'Towards a Theory' 18). Nonetheless, what Alexander and Smelzer did not recognise was that the distribution of responsibility or accountability for traumatic events does not need to lead to the construction of an antagonistic figure. On the contrary, as the Spanish case reveals, it may lead to the dissolution of any social antagonisms and to the dissolution of any accountability from the damage done as well. As I already mentioned, the Spanish Civil War was reframed as the result of a 'collective madness' which spread throughout society causing dreadful havoc and whose scars were still persisting some decades later. The Spanish Civil war thus was framed as an epidemic or an earthquake; it led to great destruction, but it lacked causal agency. The implications of its influence in the social sphere during the transition to democracy could be summarized as follows: By assuming that during those years all of Spanish society was caught up in an irrational spiral of violence, it encouraged the idea that all historical actors were both victims and perpetrators. This collective memory glosses over the asymmetrical treatment suffered by the vanquished, who were the only ones who suffered repression during the post-war period, and whose relative's bodies are the only ones which are still unidentified in common graves, eighty years later. No justice should be sought regarding the crimes committed. After all, according to this depiction, the reason behind the Spanish Civil War was a collective madness that spread throughout society. And, as Paloma Aguilar has remarked, according to Spanish criminal law, acting under the influence of a 'temporary mental disorder' makes accountability for the crimes committed fade or even prevents a criminal lawsuit. (Aguilar 208)

Finally, the social influence of this depiction strongly contributed to the fulfilment of a moderate and shock-free institutional transition to democracy. The 'chaotic eruption of hyperbolic violence which condemned all Spanish society to an unbearable suffering 'became the crystal through which many social actors viewed the memory of the war. This depiction of the war encouraged forgetfulness throughout society as a foundation of the new democracy (Desfor 43).

Historical responsibility comes from the unfolding of events that depend directly on human action. Nonetheless, in the social and political mindset of the Spanish population, the Civil War was reframed as a natural catastrophe, for which no one should be held responsible (Erikson). Opposing Alexander and Smelzer's assumptions, the Spanish case shows that political agency behind cultural trauma does not need to lead to the creation of 'antagonistic figures'. This last consequence also challenges another effect that had been ascribed to trauma - both on the individual and collective levels. Cathy Caruth asserted that "what caused, trauma, then, is a shock that appears to work very much like a bodily threat but is in fact a break in the mind's experience of time" (Caruth, Unclaimed 61). This disruption of temporality comes from the abiding presence of a past that haunts the present. Nonetheless, the Spanish Civil War, by being re-framed as cultural trauma, is not embedded as an enduring past. On the contrary, framing the war as a chaotic and unbearable burst of violence encouraged Spanish society to look towards the future and forget the historical debt 
Trauma, Narrative and Responsibility

that came from this past. It led to creating a temporal distance from this unsettling past. As Michael Richards synthesized

Hence the ambiguities in Spain of a situation where one section of society feels that the violence of the war is intimately present while, simultaneously, another views the suffering and terror as belonging to the distant past, in part because they belong to a tradition which formerly monopolized representation of the collective trauma (Richards 339).

\section{Works Cited:}

Aguilar, Paloma. Memory and Amnesia. The Role of the Spanish Civil War in the Transition to Democracy. New York, Oxford: Berghahn Books, 2008.

Alexander, Jeffrey C. “Toward a Theory of Cultural Trauma”. Cultural Trauma and Collective Identity. Berkeley, Los Angeles, London, University of California Press, 2004: 1-30.

Alexander, Jeffrey C. Trauma. A Social Theory. Cambridge: Polity Press, 2017.

Boyd, P. Carolyn. "De la memoria oficial a la memoria histórica: La Guerra Civil y la dictadura en los textos escolares de 1939 al presente”. JULIÁ, Santos (dir.). Memoria de la guerra y del franquismo. Madrid: Taurus., 2006: 79-100.

Caruth, Cathy (ed). Trauma. Explorations in Memory. Baltimore and London: The Johns Hopkins University Press, 1995.

Caruth, Cathy. Unclaimed Experience. Trauma, Narrative, and History. Baltimore and London: The Johns Hopkins University Press, 1996.

Desfor Edless, Laura. Symbol and ritual in the new Spain. The transition to democracy after Franco. Cambridge: Cambridge University Press, 1998.

Encarnación, Omar G. Democracy Without Justice in Spain. The Politics of Forgetting. Philadelphia: University of Pennsylvania Press, 2014.

Erikson, Kai. "Notes on Trauma and Community”. Caruth, Cathy (ed). Trauma. Explorations in Memory. Baltimore and London: The Johns Hopkins University Press, 1995: 183-199.

Erikson, Kai. Everything in its Path. Destruction of Community in the Buffalo Creek Flood. New York: Simon \& Schuster, 1999.

Faber, Sebastiaan. Memory Battles of the Spanish Civil War. History, Fiction, Photography. Nashville: Vandervilt University Press, 2018.

Graham, Helen. The Spanish Republic at War. Cambridge: Cambridge University Press, 2002.

Preston, Paul. The Spanish Holocaust. Inquisition and Extermination in TwentiethCentury Spain. New York: Harper Press, 2013.

Richards, Michael. After the Civil War. Making Memory and Re-making Spain Since 1936.Cambridge: Cambridge University Press, 2013.

Rodrigo, Javier. Hasta la raíz. Violencia durante la Guerra Civil y la dictadura franquista. Madrid: Alianza, 2008.

Sánchez León, Pablo; Izquierdo Martín, Jesús. La guerra que nos han contado y la que no. Madrid: Postmetrópolis, 2017. 
Trauma, Narrative and Responsibility

Smelzer, Neil J. "Psychological Trauma and Cultural Trauma”. Cultural Trauma and Collective Identity. Berkeley, Los Angeles, London, University of California Press, 2004: 32-59. 